\title{
Male Reproductive System Finding
}

National Cancer Institute

\section{Source}

National Cancer Institute. Male Reproductive System Finding. NCI Thesaurus. Code

C117719.

Symptoms, physical examination results, and/or laboratory test results related to the male reproductive system. 